\title{
Production of very large sized scaffold-free engineered cartilage constructs from the adult equine donor- a basis for therapeutic and experimental applications in the horse
}

\author{
Walter Brehm', CécileWerren' and Pierre Mainil-Varlet ${ }^{2}$
}

Equine Clinic, Department of Clinical Veterinary Medicine, University of Berne, Switzerland' and Osteoarticular Research Group, Institute of Pathology, University of Berne, Switzerland

\begin{abstract}
Summary
The horse being a model of high interest for cartilage repair studies, the feasibility of engineering scaffold-free cartilage constructs of very large size was studied for to prepare further pre-clinical testing of such constructs in vivo. The engineering of large scaffold-free cartilage constructs from chondrocytes of adult equine donors should be demonstrated. An in vitro study was carried out with chondrocytes from adult equine donors, which had to be euthanised for reasons unrelated to the locomotor system. Cartilage biopsies were taken post mortem under surgical conditions. After digestion (pronase/collagenase), scaffold-free tissue engineered cartilage was produced from the resulting chondrocytes $(\mathrm{p} 0)$. Furthermore, chondrocytes were propagated in monolayer culture, and cartilage constructs produced from passages 1 and 2 (p1, p2). Cartilage formation was allowed for at least 6 weeks and up to 6 months. Histologic and biochemical analyses of the constructs were performed to characterise the resulting constructs. Engineered cartilage constructs up to $6 \mathrm{~cm}^{2}$ large could be produced from adult equine chondrocytes that were propagated in vitro over zero to two passages. The engineered equine cartilage appeared soft after the initial 4 weeks, but matured conceivably with time to form a dense and firm cartilage like tissue. The technology used to produce autologous, scaffold-free, engineered cartilage constructs might be applied for adult horses, but also other species including man, to generate autologous cartilage implants to cover large cartilage defects. The horse may be a good animal model to study the treatment of large cartilage defects by implantation of autologous tissue engineered cartilage constructs.
\end{abstract}

Keywords: Tissue engineering, cartilage, chondrocyte, autologous, scaffold-free

Das Tissue Engineering großer Knorpelkonstrukte aus Chondrozyten adulter Pferde - eine Basis für therapeutische und experimentelle Anwendungen

Die Spezies Pferd wird als hochinteressantes Model für Studien zur Knorpelheilung angesehen. Daher wurde die Machbarkeit der Herstellung grosser Knorpelkonstrukte untersucht als Grundlage für weiterführende präklinische Untersuchungen derartiger Konstrukte in vivo im Pferdemodell. Von adulten Pferden, die aus nicht mit dem Bewegungsapparat in Verbindung stehenden Gründen euthanasiert wurden, konnten post mortem unter chirurgischen Kautelen Knorpelbiopsien gewonnen werden. Nach Verdauung (Pronase/Collagenase) wurde das Tissue Engineering der trägerfreien Knorpelkonstrukte mit einem Teil der resultierenden Chondrozyten der Passage 0 (p0) initiiert. Weiterhin wurden Chondrozyten in Monolayer-Kultur angezüchtet, und aus den resultierenden p1- und p2-Chondrozyten ebenfalls Knorpelkonstrukte angesetzt. Die Chondrogenese wurde für mindestens 6 Wochen und bis zu 6 Monaten durchgeführt. Histologische und biochemische Analysen der enstandenen Knorpelkonstrukte standen am Ende des Experimentes. Konstrukte bis zu einer Fläche von $6 \mathrm{~cm}^{2}$ konnten aus Chondrozyten adulter Pferde der Generationen p0- bis p2-produziert werden. Der entstehende Knorpel erschien nach anfänglich 4 Wochen schwach, reifte aber mit der Zeit zu einem dichten und festen Knorpelgewebe aus. Die Technologie zur Herstellung autologer, trägerfreier Knorpelkonstrukte könnte sowohl beim Pferd, als auch beim Menschen eingesetzł werden, um autologe, trägerfreie Knorpelimplantate heranzuzüchten, mit deren Hilfe grosse Knorpeldefekte behandelt werden können. Das Pferd kann ein gutes Tiermodell zur Untersuchung dieses Therapieprinzipes darstellen.

Schlüsselwörter: Tissue Engineering, Knorpel, Chondrozyt, autolog, trägerlos

\section{Introduction}

Cartilage defects are frequent and yet an unsolved problem in orthopaedics. This type of defect can significantly affect the performance of racing and sporting horses (Mcllwraith et al. 1987). Especially defects of critical size, extending to a surface area above the limits of spontaneous healing, impose attempts to stimulate a functional repair of the articular cartilage surface. In the horse, this critical size has been defined to be a defect diameter of $>3 \mathrm{~mm}$ (Convery et al. 1972).
Besides the size, the location of the lesion plays an important role for its healing, as small lesions $(5 \mathrm{~mm}$ in diameter, $\sim 0.2$ $\mathrm{cm}^{2}$ ) created in the femoropatellar joint can exhibit functional healing, while the same size of lesion would not heal in loaded joints, e.g. the femorotibial or carpal joints (Hurtig et al. 1988).

A variety of techniques has been used to treat this condition, as extensively reviewed recently (Hunziker 2002). Among the 
treatment options tested in the equine species are débridement and micro-fracturing of the cartilage defect (Frisbie et al. 1999, Frisbie et al. 2003), subchondral drilling (Vachon et al. 1986), application of periosteal flaps (Vachon et al. $1991 \mathrm{a}$, Vachon et al. $1991 \mathrm{~b}$ ), and the transplantation of sternal osteochondral autografts (Howard et al. 1994), allogeneic osteochondral grafts (Hurtig 1989) or fresh osteochondral autografts (Hurtig et al. 2001, Bodo et al. 2004). Cell based therapies were studied in the horse, such as the application of autologous chondrocytes in fibrin glve (Nixon et al. 1999, Fortier et al. 2002), beneath a periosteal flap (Litzke et al. 2004) or seeded onto a scaffold (Sams et al. 1995), and including genetically engineered cells (Hidaka et al. 2003).

In man, the defect size plays a major role in the decision for a specific treatment option. For smaller defects up to $2 \mathrm{~cm} 2$ (diameter of $\sim 16 \mathrm{~mm}$ ) in size, either the microfracturing technique or Pridie-drilling is recommended (Pridie 1959, Miller et al. 2004). Defects of intermediate size (up to $3 \mathrm{~cm} 2$, diameter of $\sim 20 \mathrm{~mm}$ ) are usually subjected to mosaicplasty. Defects larger than $3 \mathrm{~cm} 2$ need to be treated according to a cell-based strategy (Peterson et al. 2000).

Engineered cartilage constructs provide close cell interaction in a three-dimensional (3D) configuration, which appears to be a major requirement for the initiation of chondrogenesis in vitro (Watt 1988, Fedewa et al. 1998, Mackay et al. 1998; Freed et al. 1999), and for chondrocyte survival (Ishizaki et al. 1994).

A variety of materials have been tried to revert or maintain the chondrogenic phenotype, including alginate (Bruckner et al. 1989, Hauselmann et al. 1994, Chubinskaya et al. 2001), collagen gels (Kimura et al. 1984), fibre fleece scaffolds of polyhydroxy acids (Vacanti et al. 1991, Freed et al. 1993, Sittinger et al. 1996, Rudert et al. 1998, Sittinger et al. 1999), fibrin gels (Fortier et al. 1997, Fortier et al. 1998) and hyaluronic acid carriers/sponges (Butnariu-Ephrat et al. 1996, Solchaga et al. 1999). Combinations of these materials have also been utilised, such as polymer fleece cultures that are coated with a gel or semi-permeable membranes, to help retain matrix components (Sittinger et al. 1996). In the field of orthopaedics, many of these substances have been the focus of groups striving to produce artificial cartilaginous constructs, especially as means of producing an implant for use in repairing articular defects (Minuth et al. 1998; Rudert et al. 1998, Temenoff and Mikos 2000). All of the earlier-mentioned systems have been demonstrated to create permissive conditions for the process of chondrogenesis and to create de novo tissue consistent, at least biochemically, with cartilaginous tissue.

However, a majority of these methods are cumbersome, technically demanding and require the service of a scaffold. The scaffold materials themselves, however, may have negative effects on the construct (Fortier et al. 1998), and in spite of successful cartilage engineering, problems of uneven degradation of biomaterial, and unforseeable cell-biomaterial interaction remain (Naumann et al. 2004). In view of the goal to produce cartilaginous constructs for in vivo implantation for repair of articular defects, a system that produces suitable implants with the most basic of conditions was thus desirable. A system has been developed which permits chondrogenesis in the protective environment of a simple closed chamber system that does not employ a scaffold or any complicated perfusion technologies (Grogan et al. 2003).

Scaffold-free, engineered cartilage constructs of this type have consequently been produced from chondrocytes of several animal species including the pig (Mainil-Varlet et al. 2001), rabbit (Aklin et al. 2004) and goat (Brehm et al. 2004), and from human chondrocytes (unpublished laboratory data), the implantation in vivo of autologous constructs yielding encouraging results (Mainil-Varlet et al. 2001, Aklin et al. 2004, Brehm et al. 2004).

Small animal models, like the rabbit, and large animal models, like the goat and horse, are needed for the testing of treatment principles for cartilage restoration. A recent hearing of the FDA Cellular, Tissue, and Gene Therapies Advisory Committee (FDA 2005) revealed particularly the need for the equine model, as the downscaling of the large size cartilage defects is deemed inappropriate. The equine model is the only one offering the necessary size, structure and thickness of cartilage for these testing purposes.

It is the purpose of this study, therefore, to evaluate the feasibility to tissue engineer large pieces of cartilage in a scaffoldfree environment as a prerequisite for further investigation of this treatment modality in the horse.

\section{Material and Methods}

\section{Cartilage harvest}

Cartilage biopsies were taken from the fetlock joints of a 2.5year old colt and from the stifle joint of a 10 year old mare of the swiss Franche Montagne breed, which were euthanised for reasons unrelated to the locomotor system. The biopsies were taken post mortem from the trochlea ossis femoris, the condylus femoris lateralis et medialis and the caput ossis metacarpalis III through arthrotomy under surgical conditions. The cartilage specimens were kept in transport medium (D-MEM/F12: Dulbecco's Modified Eagle Medium/ Nutrient mixture F12, Life Technologies, Switzerland, containing 500 $\mathrm{U} / \mathrm{ml}$ Penicillin and $500 \mathrm{mg} / \mathrm{ml}$ Streptomycin, both from Life Technologies, Switzerland) until further processing (within 24 h of sample collection).

\section{Chondrocyte isolation}

Chondrocytes were extracted from the cartilage by enzymatic digestion according to the routine of the laboratory. Cartilage specimens were finely diced in phosphate-buffered saline (PBS) and incubated for $60 \mathrm{~min}$ with $2.5 \mathrm{mg} / \mathrm{ml}$ pronase (Roche, Switzerland) in digestion medium (digestion media: D-MEM/F1 2 containing $1 \mathrm{mg} / \mathrm{ml}$ bovine insulin, Life Technologies, Switzerland; $50 \mathrm{mg} / \mathrm{ml}$ ascorbic acid, Fluka, Switzerland; $10 \mathrm{ml} / \mathrm{g}$ of wet tissue) in a shaking water bath at $37^{\circ} \mathrm{C}$. After removal of pronase and washing with PBS digestion was continued by addition of $250 \mathrm{mg} / \mathrm{ml}$ of collagenase-P (Roche, Switzerland) in digestion medium $(10 \mathrm{ml} / \mathrm{g}$ of wet tissue) in a shaking water bath at $37^{\circ} \mathrm{C}$. The resulting cell suspension was filtered through a $100 \mathrm{~mm}$ nylon cell strainer 
(Becton-Dickinson, Switzerland) to remove debris. Cells were centrifuged (Sorvall, RT6000D; rotor 1000B) at $1800 \mathrm{rpm}$ $(675 \mathrm{xg})$ for $6 \mathrm{Min}$. at $10^{\circ} \mathrm{C}$ and washed twice with PBS, counted, and cryopreserved in 90\% Serum and 10\% DMSO (Sigma, Germany) or plated in tissue culture flasks for chondrocyte culture.

\section{Cartilage engineering}

Scaffold free cartilage was engineered from the resulting chondrocytes according to a protocol which was developed for the application in human patients, and which has been described earlier (Grogan et al. 2003). Briefly, the purified chondrocytes were propagated in tissue dishes in DMEM /F12 in monolayer culture, in the presence of $2 \%$ FCS, 10 $\mathrm{ng} / \mathrm{ml} \alpha$-FGF and $1 \mathrm{ng} / \mathrm{ml}$ TGF- $\alpha 1$. Engineered cartilage constructs were produced from passages 0,1 and $2(p 0, p 1$, $\mathrm{p} 2)$. The chondrocytes were then seeded into the static chambers (Fig. 1). Two sizes of chambers with surface areas

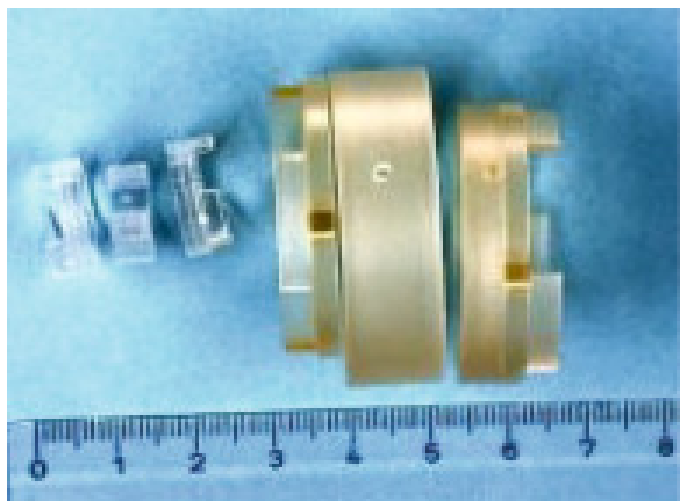

Fig 1 Production chambers for smaller (left, $0.8 \mathrm{~cm}^{2}$ ) and large (right, $6 \mathrm{~cm}^{2}$ ) engineered cartilage constructs. Through modification of the form to oval, typical large cartilage defects of the human condylus femoris might be tested in the horse and treated in human patients with these constructs in future.

Kammern für die Herstellung kleinerer (links, $0.8 \mathrm{~cm}^{2}$ ) und großer (rechts, $6 \mathrm{~cm}^{2}$ ) Knorpelkonstrukte. Durch die Veränderung der Form in ein Oval könnte die Behandlung der typischen großen Knorpeldefekte des menschlichen Condylus femoris im Pferdemodell simuliert werden, bevor sie beim Menschen eingesetzt werden.

of $0.8 \mathrm{~cm}^{2}$ and $6 \mathrm{~cm}^{2}$ were used in the present study. For this purpose, the original smaller reactor of $0.8 \mathrm{~cm}^{2}$ (Grogan et al. 2003) has been modified to produce constructs of large size.

\section{Experiment 1}

For this preliminary feasibility experiment, $\mathrm{p} 0$ cells from the younger donor were used to produce a series of 6 cartilage constructs in the smaller $\left(0.8 \mathrm{~cm}^{2}\right)$ chamber $)$. Chondrocytes were seeded at densities of $8 \times 10^{6} /$ chamber. After 46 days of culture, collagen contents ranging from 12.1 to $12.9 \mathrm{mg} / \mathrm{g}$ tissue, and chondroitinsulphate contents ranging from 10.2 to $12.5 \mathrm{mg} / \mathrm{g}$ tissue were found in the constructs. Based on this experiment, the transfer of the technology to produce equine cartilage constructs seemed possible and the main experiment (experiment 2) was carried out.

\section{Experiment 2}

PO cells were seeded directly at a density of $2 \times 10^{6}, 4 \times 10^{6}$ and $8 \times 10^{6}$ into the static chambers, and 3 constructs were produced at each density. P1 and p2 cells were seeded at $8 \times 10^{6}$ cells only to produce a further 3 constructs. Cartilage formation was allowed for at least 6 weeks, the constructs being maintained in vitro for up to 6 months. The engineered constructs of experiment 2 were examined more extensively and therefore, the following methods, results and discussion are given with respect to experiment 2 exclusively.

\section{Biochemical analysis}

To determine the content of collagen and sulphated glycosaminoglycans, the engineered cartilage constructs were hydrolyzed in $4 \mathrm{M} \mathrm{NaOH}$ at $120^{\circ} \mathrm{C}$ for $30 \mathrm{~min}$. The amount of the extracted hydroxyproline was spectroscopically determined after its reaction with $\mathrm{p}$-dimethylaminobenzaldehyde and chloramine T (Schwartz et al. 1985). Alternatively, the constructs were solubilized with papain and proteoglycans were extracted with $4 \mathrm{M}$ guanidinium chloride (Grogan et al. 2003). The consecutive reactant with dimethylene blue (DMB) was determined by colorimetry (Farndale et al. 1986) to quantify the suphated glycosaminoglycans, whereby chondroitin sulphate was used to calibrate the standard curve.

\section{Macroscopic evaluation of construct quality}

A visual scale (grades $1 / 1.5 / 2 / 2.5 / 3$ ) was used to classify the engineered constructs. This scale is based on the experience of the laboratory and describes the quality subjectively in terms of thickness, hardness and overall appearance of the construct between poor (grade 1) and very good (grade 3). In addition to this, the wet weight of the constructs was monitored periodically.

Histology

For light microscopy, Safranin-O/Fast Green and Alcian Blue stainings were applied. To determine the viability of the chondrocytes within the constructs, a supravital staining was used (Live-Dead ${ }^{\circledR}$, Juro, Switzerland). Furthermore, immuno-histochemistry for collagen types I and II was performed.

\section{Results}

Chondrocyte isolation yields

Chondrocytes were obtained from cartilage of the femoral condyle, the femoral trochlea and the fetlock joint. The yields were very similar and resulted in 8.7 and $6.1 \times 10^{6}$ cells per gram of tissue for condylar and trochlear cartilage, respectively.

\section{Chondrocyte expansion}

Both populations required between 2.0 and 2.5 days for one generation during passage 0 . In the following passages the generation time was reduced to 1.0 day. 
Production of very large sized scaffold-free engineered cartilage constructs from the adult equine donor - a basis for therapeutic and experimental applications in the horse

\section{Scaffold-free cartilage construct production}

Influence of seeding density

Macroscopic quality (1.5 / 3 in all cases, $n=12$ ) two weeks after seeding was very similar for all seeding densities and construct sizes. The chambers seeded with $2 \times 10^{6}(n=3)$ and $4 \times 10^{6}$ chondrocytes $(n=3)$ contained very thin cartilage constructs at this stage. After 4 weeks, the constructs produced from $2 \times 10^{6}$ chondrocytes were still very thin $(0.5$ $1 / 3)$, while the constructs produced from $4 \times 10^{6}$ cells (22.5 / 3) were similar in macroscopic quality to the constructs produced from $8 \times 10^{6}$ chondrocytes $(2.5 / 3, n=3)$, the constructs having reached a thickness of about $1 \mathrm{~mm}$. Based on this observation, long-term culture of constructs was carried out on the basis of $8 \times 10^{6}$ chondrocytes exclusively $(n=3)$.

\section{Influence of passage}

Scaffold-free cartilage constructs could be produced from $\mathrm{p} 0$, p1 and p2 adult equine chondrocytes. The growth patterns in vitro of equine cartilage were similar to human cartilage grown under identical conditions (laboratory experience, data not shown). The cartilage constructs appeared thin and soft during the first 4 weeks. After this time, their quality changed to a more dense and firm consistency, and total construct weight and mechanical stability increased during the maturation period (data not shown). Neither the cell source (trochlea versus condylus) nor the passage number had an influence on the macroscopic appearance of the constructs (Fig. 2).

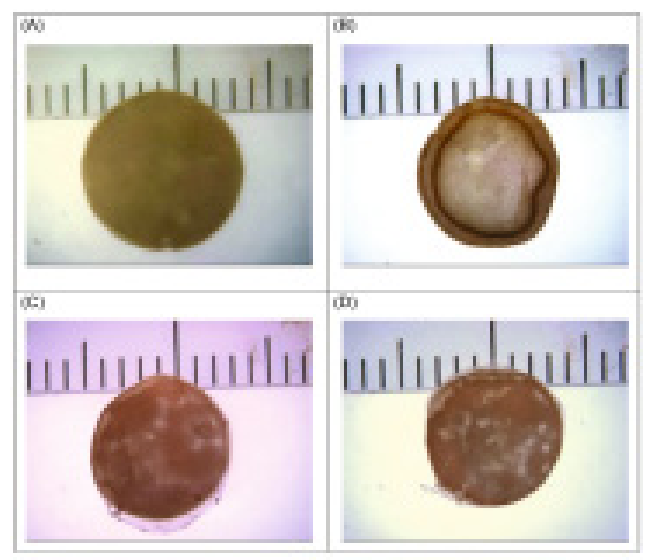

Fig 2 Representative engineered cartilage constructs formed out of chondrocytes that were obtained from condyles (A and $C$ ) and trochlea $(B$ and $D)$. Either chondrocytes from passage $O$ ( $A$ and $B$ ) or chondrocytes from passage 1 ( $C$ and $D)$ were used for cartilage formation. Pictures were taken 4 weeks post induction of cartilage matrix formation.

Repräsentative Knorpelkonstrukte aus Chondrozyten des Condylus (A und $C$ ) und der Trochlea (B und D). Die Chondrozyten stammen aus Passage 0 ( $A$ und $B$ ) oder Chondrocyten aus Passage 1 ( $C$ und D). Abgebildet ist der Zustand 4 Wochen nach Induktion der Knorpelneubildung.

Chondrocyte viability within the construct.

The development of the constructs during maturation was correlated with high cell viability within the constructs, which yielded about $85 \%$ live cells after 10 weeks in culture when controlled with confocal microscopy (Fig.3).

\section{Construct biochemistry}

Influence of cell source (trochlea versus condylus)

Independently of the source of the chondrocytes the implants consisted of similar concentrations of sulphated glycosaminoglycans and collagen (Fig.4). The engineered cartilage contained amounts of sulphated glycosaminoglycans in the range of native cartilage. However, the collagen concentration was reduced about 5 -fold in the engineered tissue compared to its native source (Fig.4).

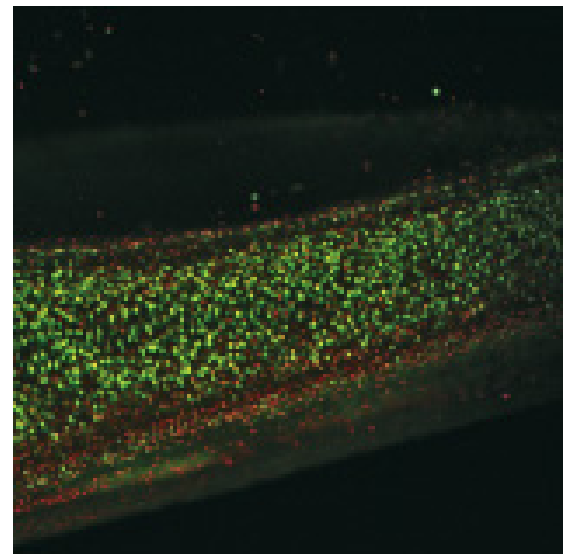

Fig 3 Chondrocyte viability (Live-Dead ${ }^{\circledR}$-staining, 10 weeks of culture). $85 \%$ cell viability is detected by the green fluorescent stain of this supravital method.

Vitalität der Chondrozyten nach 10 Wochen (Live-Dead ${ }^{\circledR}$ _Färbung). 85 \% der Zellen erscheinen vital, wie durch die grüne SupravitalAnfärbung gezeigt wird.

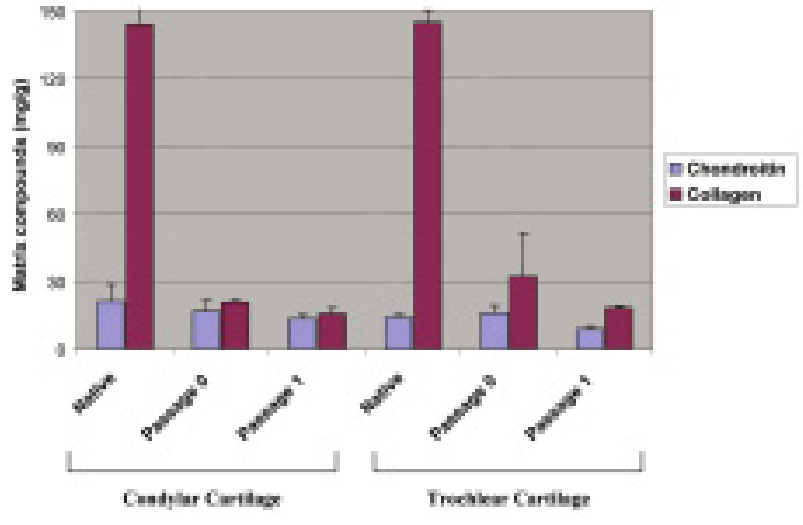

Fig 4 Sulphated glycosaminoglycan (chondroitin) and collagen content of native equine cartilage from the condyle or the trochlea in comparison to engineered cartilage that was produced after the chondrocytes were propagated in culture for zero or one passage. The matrix compounds are expressed in ratio to the wet weight of the corresponding tissue.

Sulphatierte Glycosaminoglykane (Chondroitin) und Kollagen im Vergleich nativen Pferdeknorpels von Condylus femoris und Trochlea femoris mit neugezüchteten Knorpelkonstrukten aus Chondrozyten der Passagen 0 oder 1. Die Konzentration der Matrixkomponenten sind im Verhältnis zum Nassgewicht der entsprechenden Gewebe dargestellt.

\section{Influence of culture time}

The relative concentration of collagen increased slightly over time in this experiment. The collagen concentrations were 5 to 6 times lower than in native cartilage in all of the cases, 
however (Fig.5). The relative concentration of sulphated glycosaminoglycans was at half the value for native cartilage at 6 weeks, and reached values near normal at 20 weeks of culture, while being much lower before (10 weeks) and afterwards (30 weeks) (Fig.5).

\section{Histology and Immuno-Histochemistry}

The histologic and immuno-histochemical images show the clear similarity of the scaffold-free, engineered cartilage constructs with hyaline cartilage state. The high cellular density without any functional organization of the cells is characteristic of immature cartilage. Intense staining for proteoglycans and collagen II, and weak staining for collagen I, define this type of tissue (Fig.6).

\section{Discussion}

Isolation, propagation and cryopreservation of equine chondrocytes has been reported earlier (Nixon et al. 1992). These authors used fetuses and newborn foals as donors, while our donors were adult horses of an age, which is clinically relevant for the eventual treatment of cartilage defects.

Monolayer culture and 3-D-culture were feasible, in accordance with literature (Nixon et al. 1992). However, a doubling time of 1 to 2.5 days was observed in our study, while these authors reported a doubling time of 6 days (Nixon et al. 1992).

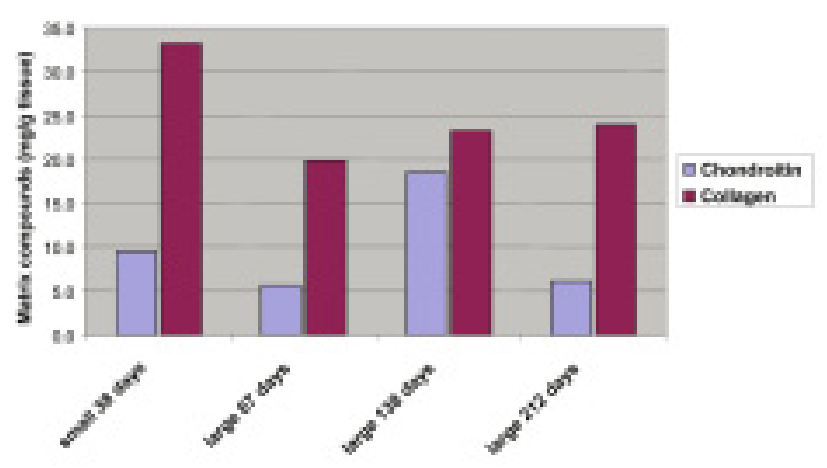

Fig 5 Sulphated glycosaminoglycans (chondroitin) and collagen of equine cartilage constructs that were matured over a time period of up to 212 days. The implants were generated from a mixture of chondrocytes from the condylar and trochlear cartilage after two passages. The matrix compounds are expressed in ratio to the wet weight of the corresponding tissue.

Sulphatierte Glycosaminoglykane (Chondroitin) und Kollagen equiner Knorpelkonstrukte, die über einen Zeitraum von bis zu 212 Tagen in Kultur gehalten wurden. Die Implantate wurden aus einer Mischung von Passage-2-Chondrozyten des Condylus und der Trochlea angezüchtet. Die Konzentrationen der Matrixkomponenten sind im Verhältnis zum Nassgewicht der entsprechenden Gewebe dargestellt.

The tissue produced in the scaffold-free system from equine chondrocytes has cartilage-like qualities in terms of production of relative high amounts of collagen type II versus collagen type I and the deposition of extracellular matrix mainly consisting of glycosaminoglycans. After 4 weeks, most of the constructs appeared very soft, but after 8 weeks, the consistency had changed to a quality, which could be handled easily with forceps and, therefore, would allow implantation into an in vivo environment. These findings are in accordance with observations made in the same system in other species, namely the minipig (Mainil-Varlet et al. 2001), the rabbit (Aklin et al. 2004) and the goat (Brehm et al. 2004) and is in accordance with another study using equine material (Sun et al. 2002). However, this group used cartilage biopsies from the stifle joint of foals and discussed the potentially infe-
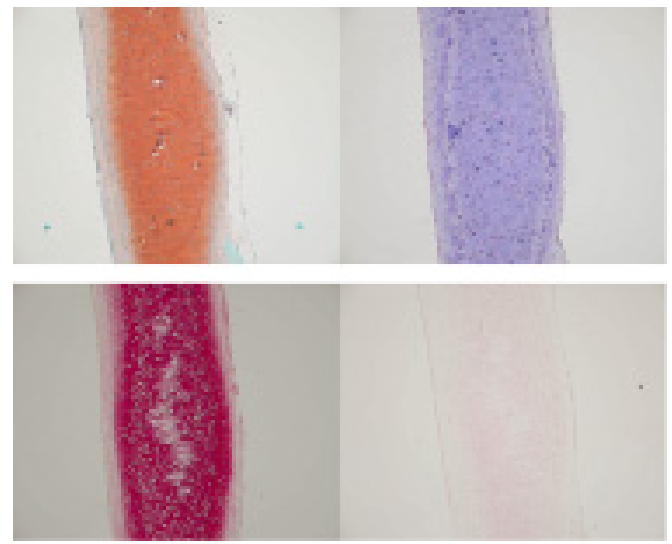

Fig 6 Intense staining for proteoglycans (Safranin-O (A), Alcian Blue (B)) and collagen II (C), and weak staining for collagen I (D) define this tissue.

Die intensive Anfärbung der Proteoglykane (Safranin-O (A), Alcian Blau (B)) und des Kollagen II (C), und die schwache Anfärbung des Kollagen I (D) sind charakteristisch für hyalinen Knorpel.

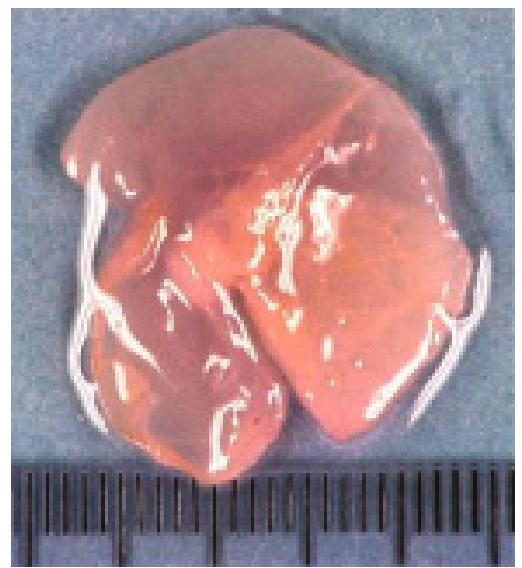

Fig 7 Large $\left(6 \mathrm{~cm}^{2}\right)$ equine scaffold-free engineered cartilage construct. The construct appears thinner at the site of the stabilizing bars of the culture chamber. Through modification of the chamber, this uneven appearance will be avoided in future.

Große $\left(6 \mathrm{~cm}^{2}\right)$ trägerfreie Knorpelkonstrukte aus Pferde-Chondrozyten. Das Konstrukt erscheint dünner an den Stellen, wo die die Kulturkammer stabilisierenden Streben liegen. Durch konstruktive Veränderungen an der Kammer wird dieses uneinheitliche Erscheinungsbild zukünftig vermieden werden.

rior capacity of chondrocytes from adult donors to produce neo-cartilage. We were able to grow cartilage constructs from the adult equine donor and therefore, age may not be a limiting factor. Similar observations have been made in man, where the production of neo-cartilage could be shown using chondrocytes from aged persons (Marlovits et al. 2003). 
While the ratio of collagen type II versus collagen type I is indicative of chondrogenesis, the total amount of collagen is not in the range of native cartilage. This might be due to the lack of mechanical stimuli, like shear and compressive forces applied to the constructs. Indeed, such stimulation would result in higher collagen concentrations, which has been shown in another study of our group (Brehm et al. 2006a). The structural alignment of the collagens would be another aspect of interest which has not been investigated in this study. Whether or not the creation of a more mature native cartilage like construct would result in better repair capacity within cartilage defects would have to be tested in vivo, however.

Glycosaminoglycan contents reached levels near normal and showed a relatively stable development in the long term culture, with the exception of week 20, where they were much higher. This observation confirms the stability of the constructs in culture; the peak level of glycosaminoglycans cannot be explained, however, and the long term development of cartilaginous constructs would have to be re-evaluated for further assessment.

This is the first report about the production of scaffold-free engineered cartilage constructs from an adult horse, and also the first report about the production of construct of a size, which is in the range of large, clinically relevant cartilage defects in equine and human patients (Fig.7). The potential for the clinical use of such constructs has recently been demonstrated in the goat model, where the cartilaginous constructs were implanted into defects within the trochlea femoris (Brehm et al 2006b). This site of implantation has the advantage of not being loaded with share forces and compressive forces to the same extent as the condylus femoris, where high rates of implant loss have been observed (Aklin et al. 2003, Vasara et al. 2004). It will therefore, be necessary to take measures as immobilization or at least restriction of motion to successfully implant cartilaginous constructs. Hence, in the horse, the fetlock joint and the carpal joints might be more appropriate for the application of such techniques than the femoro-tibial joints.

The horse may thus be used as an animal model to study the treatment of cartilage defects by implantation of scaffold-free, autologous tissue engineered cartilage.

Further studies are now needed to test implantation, survival and transformation of our immature engineered cartilage constructs in vivo.

\section{Literature}

Aklin B., W. Brehm and P. Mainil-Varlet (2003): Periosteal flap loosening rate in a caprine chondral defect model Osteoarthritis and Cartilage 11 Suppl A, 107

Aklin B., F. Rieser, T. Trüb, S. Grogan, V. Windelmann, R. Jakob and P. Mainil-Varlet (2004): Articular cartilage repair using DENOVO$\mathrm{T}^{\mathrm{TM}}$, a scaffold-free cartilage-like implant. 5th ICRS Meeting, Gent, Belgium, ICRS

Bodo G., L. Hangody, L. Modis and M. Hurtig (2004): Autologous osteochondral grafting (mosaic arthroplasty) for treatment of subchondral cystic lesions in the equine stifle and fetlock joints. Vet Surg 33, 588-596
Brehm W., B. Aklin, T. Yamashita, F. Rieser, T. Trüb and P. Mainil-Varlet (2004): Cartilage repair using tissue engineered cartilage in a caprine superficial osteochondral defect model. Vet Surg 33, E 10

Brehm W., U. Graf and P. Mainil-Varlet (2006a): Steps towards cartilage repair with engineered scaffold-free autologous cartilage constructs. in: Brittberg, M., M. Marcacci, S. Zanasi (Ed.): Basic Science, Clinical Repair and Reconstruction of Articular Cartilage Defects: Current Status and Prospects. Timeo Editore, Bologna, Chapter 89

Brehm W., B. Aklin, T. Yamashita, F. Rieser, T. Trüb and P. Mainil-Varlet (2006b): Repair of superficial osteochondral defects with an autologous scaffold-free cartilage construct in a caprine model: implantation method and short term results. Osteoarthritis and Cartilage available online 3 July 2006

Bruckner P., I. Horler, M. Mendler, Y. Houze, K. H. Winterhalter, S. G. Eich-Bender and (1989): Induction and prevention of chondrocyte hypertrophy in culture. J Cell Biol 109, 2537-2545

Butnariu-Ephrat, M., D. Robinson, D. G. Mendes, N. Halperin and Z. Nevo (1996): Resurfacing of goat articular cartilage by chondrocytes derived from bone marrow. Clin Orthop, 234-243

Chubinskaya S., K. Huch, M. Schulze, L. Otten, M. B. Aydelotte and A. A. Cole (2001): Gene expression by human articular chondrocytes cultured in alginate beads. J Histochem Cytochem 49, $1211-1220$

Convery F. R., W. H. Akeson and G. H. Keown (1972): The repair of large osteochondral defects. An experimental study in horses. Clin Orthop 82, 253-262

Farndale R. W., D. J. Buttle and A. J. Barrett (1986): Improved quantitation and discrimination of sulphated glycosaminoglycans by use of dimethylmethylene blue. Biochim Biophys Acta 883, 173177

FDA (2005): Meeting \# 38: Cellular Products for Joint Surface Repair. FDA Cellular, Tissue, and Gene Therapies Advisory Committee. Rockville, MD, FDA

Fedewa M. M., T. R. Oegema, Jr., M. H. Schwartz, A. MacLeod and J. L. Lewis (1998): Chondrocytes in culture produce a mechanically functional tissue. J Orthop Res 16, 227-236

Fortier L. A., P. J. Brofman, A. J. Nixon and H. O. Mohammed (1998): Disparate chondrocyte metabolism in three-dimensional fibrin cultures derived from autogenous or commercially manufactured fibrinogen. Am J Vet Res 59, 514-520

Fortier L. A., H. O. Mohammed, G. Lust and A. J. Nixon (2002): Insulin-like growth factor-I enhances cell-based repair of articular cartilage. J Bone Joint Surg Br 84, 276-288

Fortier L. A., A. J. Nixon, H. O. Mohammed and G. Lust (1997): Altered biological activity of equine chondrocytes cultured in a threedimensional fibrin matrix and supplemented with transforming growth factor beta-1. Am J Vet Res 58, 66-70

Freed L. E., J. C. Marquis, A. Nohria, J. Emmanual, A. G. Mikos and $R$. Langer (1993): Neocartilage formation in vitro and in vivo using cells cultured on synthetic biodegradable polymers. J Biomed Mater Res 27, 11-23

Freed, L. E., I. Martin and G. Vunjak-Novakovic (1999): Frontiers in tissue engineering. In vitro modulation of chondrogenesis. Clin Orthop, S46-58.

Frisbie D. D., J. T. Oxford, L. Southwood, G. W. Trotter, W. G. Rodkey, J. R. Steadman, J. L. Goodnight and C. W. Mcllwraith (2003): Early events in cartilage repair after subchondral bone microfracture. Clin Orthop, 215-227

Frisbie D. D., G. W. Trotter, B. E. Powers, W. G. Rodkey, J. R. Steadman, R. D. Howard, R. D. Park and C. W. Mcllwraith (1999): Arthroscopic subchondral bone plate microfracture technique augments healing of large chondral defects in the radial carpal bone and medial femoral condyle of horses. Vet Surg 28, 242-255

Grogan S. P., F. Rieser, V. Winkelmann, S. Berardi and P. Mainil-Varlet (2003): A static, closed and scaffold-free bioreactor system that permits chondrogenesis in vitro. Osteoarthritis Cartilage 11, 403-41 1

Hauselmann H. J., R. J. Fernandes, S. S. Mok, T. M. Schmid, J. A. Block, M. B. Aydelotte, K. E. Kuettner and E. J. Thonar (1994): Phenotypic stability of bovine articular chondrocytes after longterm culture in alginate beads. J Cell Sci 107 ( Pt 1), 17-27 
Hidaka C., L. R. Goodrich, C. T. Chen, R. F. Warren, R. G. Crystal and A. J. Nixon (2003): Acceleration of cartilage repair by genetically modified chondrocytes over expressing bone morphogenetic protein-7. J Orthop Res 21, 573-583

Howard R. D., C. W. Mcllwraith, G. W. Trotter, B. E. Powers, P. R. McFadden, F. L. Harwood and D. Amiel (1994): Long-term fate and effects of exercise on sternal cartilage autografts used for repair of large osteochondral defects in horses. Am J Vet Res 55, 1158-1167

Hunziker E. B. (2002): Articular cartilage repair: basic science and clinical progress. A review of the current status and prospects. Osteoarthritis Cartilage 10, 432-463

Hurtig M., S. Pearce, S. Warren, M. Kalra and A. Miniaci (2001) :Arthroscopic mosaic arthroplasty in the equine third carpal bone. Vet Surg 30, 228-239

Hurtig M. B. (1989): Experimental use of small osteochondral grafts for resurfacing the equine third carpal bone. Equine Vet J, 23-27

Hurtig M. B., P. B. Fretz, L. E. Doige and D. Schnurr (1988): Effect of lesion size and location on equine articular cartilage healing. Can J Vet Res 52, 137-146

Ishizaki Y., J. F. Burne and M. C. Raff (1994): Autocrine signals enable chondrocytes to survive in culture. J Cell Biol 126, 1069-1077

Kimura T., N. Yasui, S. Ohsawa and K. Ono (1984): Chondrocytes embedded in collagen gels maintain cartilage phenotype during long-term cultures. Clin Orthop, 231-239

Litzke L. E., E. Wagner, W. Baumgaertner, U. Hetzel, O. JosimovicAlasevic and J. Libera (2004): Repair of extensive articular cartilage defects in horses by autologous chondrocyte transplantation. Ann Biomed Eng 32, 57-69

Mackay A. M., S. C. Beck, J. M. Murphy, F. P. Barry, C. O. Chichester and M. F. Pittenger (1998): Chondrogenic differentiation of cultured human mesenchymal stem cells from marrow. Tissue Eng 4, 415-428

Mainil-Varlet P., F. Rieser, S. Grogan, W. Mueller, C. Saager and R. P. Jakob (2001): Articular cartilage repair using a tissue-engineered cartilage-like implant: an animal study. Osteoarthritis Cartilage 9 Suppl A, S6-15

Marlovits S., B. Tichy, M. Truppe, D. Gruber and V. Vecsei (2003): Chondrogenesis of aged human articular cartilage in a scaffoldfree bioreactor. Tissue Eng 9, 1215-1226

Mcllwraith C. W., J. V. Yovich and G. S. Martin (1987): Arthroscopic surgery for the treatment of osteochondral chip fractures in the equine carpus. J Am Vet Med Assoc 191, 531-540

Miller B. S., J. R. Steadman, K. K. Briggs, J. J. Rodrigo and W. G. Rodkey (2004): Patient satisfaction and outcome after microfracture of the degenerative knee. J Knee Surg 17, 13-17

Minuth W. W., M. Sittinger and S. Kloth (1998): Tissue engineering: generation of differentiated artificial tissues for biomedical applications. Cell Tissue Res 291, 1-11

Naumann A., J. E. Dennis, J. Aigner, J. Coticchia, J. Arnold, A. Berghaus, E. R. Kastenbaver and A. I. Caplan (2004): Tissue engineering of autologous cartilage grafts in three-dimensional in vitro macroaggregate culture system. Tissue Eng 10, 1695-1706

Nixon A. J., L. A. Fortier, J. Williams and H. Mohammed (1999): Enhanced repair of extensive articular defects by insulin-like growth factor-I-laden fibrin composites. J Orthop Res 17, 475487

Nixon A. J., G. Lust and M. Vernier-Singer (1992): Isolation, propagation, and cryopreservation of equine articular chondrocytes. Am J Vet Res 53, 2364-2370.
Peterson L., T. Minas, M. Brittberg, A. Nilsson, E. Sjogren-Jansson and A. Lindahl (2000): Two- to 9-year outcome after autologous chondrocyte transplantation of the knee. Clin Orthop, 212-234

Pridie K. H. (1959): JBJS-Br 41, 618-619

Rudert M., C. J. Wirth, M. Schulze and G. Reiss (1998): Synthesis of articular cartilage-like tissue in vitro. Arch Orthop Trauma Surg 117, 141-146

Sams A. E., R. R. Minor, J. A. Wootton, H. Mohammed and A. J. Nixon (1995): Local and remote matrix responses to chondrocyteladen collagen scaffold implantation in extensive articular cartilage defects. Osteoarthritis Cartilage 3, 61-70

Schwartz D. E., Y. Choi, L. J. Sandell and W. R. Hanson (1985): Quantitative analysis of collagen, protein and DNA in fixed, paraffin-embedded and sectioned tissue. Histochem J 17, 655-663

Sittinger M., C. Perka, O. Schultz, T. Haupl and G. R. Burmester (1999): Joint cartilage regeneration by tissue engineering. Z Rheumatol 58, 130-135

Sittinger M., D. Reitzel, M. Dauner, H. Hierlemann, C. Hammer, E. Kastenbaver, H. Planck, G. R. Burmester and J. Buiia (1996): Resorbable polyesters in cartilage engineering: affinity and biocompatibility of polymer fiber structures to chondrocytes. J Biomed Mater Res 33, 57-63

Solchaga L. A., J. E. Dennis, V. M. Goldberg and A. I. Caplan (1999): Hyaluronic acid-based polymers as cell carriers for tissueengineered repair of bone and cartilage. J Orthop Res 17, 205213

Sun Y., H. Chen, R. Kandel and M. Hurtig (2002): Characterisation of reconstituted equine cartilage formed in vitro. Equine Vet J 34, 373-377

Temenoff J. S. and A. G. Mikos (2000): Review: tissue engineering for regeneration of articular cartilage. Biomaterials 21, 431-440

Vacanti C. A., R. Langer, B. Schloo and J. P. Vacanti (1991): Synthetic polymers seeded with chondrocytes provide a template for new cartilage formation. Plast Reconstr Surg 88, 753-759

Vachon A., L. R. Bramlage, A. A. Gabel and S. Weisbrode (1986): Evaluation of the repair process of cartilage defects of the equine third carpal bone with and without subchondral bone perforation. Am J Vet Res 47, 2637-2645

Vachon A. M., C. W. Mcllwraith and F. W. Keeley (1991a): Biochemical study of repair of induced osteochondral defects of the distal portion of the radial carpal bone in horses by use of periosteal autografts. Am J Vet Res 52, 328-332

Vachon A. M., C. W. Mcllwraith, G. W. Trotter, R. W. Norrdin and B. E. Powers (1991b): Morphologic study of repair of induced osteochondral defects of the distal portion of the radial carpal bone in horses by use of glued periosteal autografts [corrected]

\author{
Dr. W. Brehm \\ Equine Clinic \\ Department of Clinical Veterinary Medicine \\ University of Berne \\ Länggass-Strasse 124 \\ 3012 Bern \\ Switzerland \\ walter.brehm@knp.unibe.ch
}

\section{Röntgendiagnostik + Aktualisierungskurs}

